\title{
LOOKING AFTER YOUR GROUND: RESOURCE MANAGEMENT PRACTICE BY RAKIURA MAORI TITI HARVESTERS
}

\author{
by Jane Catherine Kitson and Henrik Moller
}

(with one text-figure)

\begin{abstract}
Kitson, J.C. \& Moller, H. 2008 (31:x): Looking after your ground: resource management practice by Rakiura Maori Titi harvesters. Papers and Proceedings of the Royal Society of Tasmania 142(1): 161-176. https://doi.org/1 10.26749/rstpp.142.1.161 ISSN 0080-4703. Centre for the Study of Agriculture, Food and Environment, University of Otago, PO Box 56, Dunedin 9054, New Zealand (JCK, HM*).*Author for correspondence. Email: henrik.moller@otago.ac.nz
\end{abstract}

\begin{abstract}
The annual harvest of Titi, Puffinus griseus, on islands adjacent to Rakiura (Stewart Island) by Rakiura Maori is one of the last large-scale customary uses of native wildlife in New Zealand. This study investigates whether Rakiura Maori harvesting practices constitute common property resource management and how these practices relate to the sustainability of Titi harvests. Semi-directive interviews were conducted with 20 experienced Titi harvesters and elders to record their matauranga Maori (Traditional Ecological Knowledge) and tikanga (lore) that govern this harvest. Access to the resource is shared and controlled by birthright. Informal and formal sanctions enforce the rules that promote sustainable use by protecting island habitat and adult birds, and minimising disturbance. These rules and other aspects of Titi harvesting practice conform to common property resource management theory. While adhering to the main resource rules, localised flexibility in management provides harvesters with the ability to adapt to changing environmental and social circumstances. Adaptive comanagement of Tiri harvesting has included turning lore into law to reinforce social institutions, integration of science and matauranga for sustainability assessments, and application of new ecosystem management tools. Environmentality is promoted by local self-government of Rakiura Maori Titi harvesting practice and island ecosystem management.
\end{abstract}

Key Words: Preffinus griseus, Titi harvesting, Traditional Ecological Knowledge, lore, adaptive co-management, environmentality.

\section{INTRODUCTION}

The term Traditional Ecological Knowledge (TEK) refers to "a cumulative body of knowledge, practice, and belief, evolving by adaptive processes and handed down through generations by cultural transmission, about the relationship of living beings (including humans) with one another and the environment" (Berkes 2008: 7). It is an attribute of societies with a long-term continuity of resource use at a particular place, especially indigenous peoples' customary use of wildlife and natural resources. TEK and associated lore is potentially crucial in determining whether customary harvests of wild foods are sustainable in a modern world of globalisation, commercialisation of markets, new harvest technologies, rising population pressure and invasive species (Newman \& Moller 2005).

Sustainable customary use of wildlife by indigenous people often involves an added challenge because the resource may be owned by an entire tribal group or harvested from communally owned land. Common property theory applies to these situations where (i) the exclusion of potential users is difficult, and (ii) the activity of each user subtracts from the welfare of all the others (Berkes 1989, Feeny et al. 1990). Achieving sustainable common property resource management requires the group to control access of all potential users and to have common property institutions. The latter include decision-making arrangements where rules for resource harvesting and sharing are made and enforced among the users themselves (Berkes 1986, 1989). Once access and resource use rules are in place, both the costs and benefits of any management action will be borne by the same individual or group, thus providing an incentive to conserve. The alternative has been characterised by Hardin (1968) as "the tragedy of the commons".

Resource use rules can be complex, vary between communities and be fine-tuned to spatial and temporal variation in ecological conditions. Their implementation may involve an intimate belief system that incorporates religious beliefs, cultural rituals and other social mechanisms alongside environmental and natural history observations (Gadgil et al. 1993, Colding \& Folke 1997, 2001, Berkes et al. 2000, 2003, Berkes 2008). Inclusion of the word "traditional" does not imply that TEK is static - indeed it builds from experience and the incorporation of useful aspects of modern technological innovation (Gadgil et al. 1993, Stevenson 1.996, Lyver \& Moller 1999a, b, Lyver 2002, Berkes 2008). Learning by doing is fundamentally important for "adaptive co-management"; the way indigenous communities respond to socio-economic and environmental changes and challenges to local governance and management (Berkes \& Turner 2006, Turner \& Berkes 2006).

Māori, New Zealand's indigenous people, use the term mátauranga for their knowledge and tikanga for their customary lore concerning resource management rules. Together they have guided natural resource use for centuries in Aotearoa New Zealand (Roberts et al. 1995, Kawharu 2002). This paper describes in detail how Rakiura Māori manage one of the last large-scale customary uses of native wildlife in New Zealand - their annual harvest of Tìtī, Puffinus griseus (J.F. Gmelin, 1789), Sooty Shearwaters or muttonbirds. Rakiura Māori is a legally-defined term based on usufructuary rights to harvesting Tìtī, as determined by whakapapa (genealogical links) to the harvesters present when the 1912 regulations were promulgated (Wilson 1979, Stevens 2006).

Some people, especially Pākehā (non-Māori people), dispute that Māori can adequately manage the New Zealand environment (Moller 1996, Taiepa et al. 1997, Newman \& Moller 2005). This belief is seen in their submissions to the Southland Conservation Board on the proposed return of the ownership of the Tìti Islands to Ngāi Tahu ownership (Southland Conservation Board 1994) and their submissions 
to the New Zealand Conservation Board on Customary Use of Wildlife (New Zealand Conservation Authority 1997). Those submissions challenged whether adequate TEK still exists amongst Māori; whether it can ever be sufficient to ensure sustainable use; and whether it can guide within new ecological conditions prevailing in New Zealand, or where new technologies may have made current harvest rates unsustainable. There were then no detailed case studies of Māori TEK applications for sustainable environmental management to evaluate these assertions, yet several New Zealand statutes directed government agents to apply Treaty of Waitangi and kaitiakitanga (Māori environmental guardianship) principles in their policy and operations (Moller et al. 2000).

Rakiura Māori established the overall Tìtī research program in 1994 primarily to examine the sustainability of the harvest to ensure that the birds remain plentiful for their mokopuna (grandchildren) (Moller 1996, Taiepa et al. 1997). Research was in part motivated by decline in Tïtĩ abundance (Scott $e t$ al. 2008), even though the absolute abundance is extremely high (Newman etal. 2008 a, b). The kaitiaki (environmental guardians) called the program Kia Mau Te Tìti Mo Ake Tōnu Atu, which means "Keep the Tìtī Forever". An immediate priority of the program was to record the matauranga of the Rakiura Titî harvesters and the ways it might promote sustainability. We also sought to provide a detailed case-study of kaitiakitanga, to provide clarification of its nature and extent, and to aid government agents in the application of environmental statutes in Aotearoa. Additionally we sought to place a Mãori example of TEK and environmental lore into the context of practices of Indigenous Peoples observed elsewhere in the world. Accordingly, the objectives of this paper are to (a) describe the mattauranga and tikanga that guide Tìtî harvest management; (b) compare these described characteristics with the TEK of Indigenous Peoples elsewhere; (c) assess whether Rakiura harvesting practices constitute common property resource management; and (d) consider ways that mātauranga and associated tikanga might promote sustainability of customary harvests.

\section{RAKIURA TITTİ HARVESTS: AN ICONIC CUSTOMARY WILDLIFE HARVEST}

Tìtī is probably the most ecologically important seabird in New Zealand (Warham \& Wilson 1982). The centre of breeding abundance is in Foveaux Strait and on 36 Tìtī ("Muttonbird") Islands around the island of Rakiura (Stewart Island) (fig. 1). Tìti nest in burrows dug by the adults in deep and soft peaty soils under a low forest canopy consisting mainly of Tüpare, Olearia colensoi Hook., and Têtéaweka, Olearia oporina Forst., tree daisies.

The Tìti harvest is a defining cultural activity for Rakiura Māori that generates social cohesion and group identity (Waitangi Tribunal 1991, Stevens 2006). Historically, Rakiura Māori would have followed a resource gathering (mahinga kai) cycle. Their movements to different locations were according to the seasons; they followed the life-cycles of the animals and plants that they depended on for survival and cultural continuation (Dacker 1990). Outside the Titi harvesting season, they would have been busy gathering other types of materials in different locations, leaving little opportunity to visit the islands. The only other abundant food sources on the islands outside the season were seals and sea-lions, which would have been far more easily obtained from accessible mainland coasts (Hawke et al. 2003). Archaeological data show that Sooty Shearwaters were widely exploited as a food and trade source in prehistoric New Zealand (Dacker 1994, Hawke et al. 2003), but their present large-scale use may have been a protohistoric phenomenon (Anderson 1997, but see Davis 1999 and Moller 1999 for a counter-view). "Muttonbirding" is a collective term for techniques and practices in which chicks of various Procellariidae seabirds are captured, processed and preserved for food (Anderson 1996, 1997). Traditional harvests are known from the north Atlantic, Australia, Raoul and Norfolk islands, and several places within New Zealand (Anderson 1996). Other than the Rakiura harvest, the only contemporary large-scale muttonbirding occurs in Tasmania, where Short-tailed Shearwater, Puffinus tenuirostris (Teminck, 1835), chicks are harvested commercially and recreationally (Skira \& Wapstra 1980, Skira et al. 1986, Skira 1990).

On 29 June 1864, the Deed of Cession of Rakiura was signed between Màori and the Crown. Together with subsequent legislation, the Deed acknowledged the hereditary rights of Māori to harvest Tìtī. "Beneficial Islands" were set aside for the use of Rakiura Màori descended from chiefs who signed the Deed. "Crown Islands" were mistakenly retained by the Crown for the use of other Rakiura Mãori who wrongly missed out on allocations on the Beneficial Islands. Rights to harvest Tìtī chicks each "birding season" (1 April-31 May) from 36 Muttonbird (Tītī) islands were first legally instituted in 1912. Associated harvesting regulations were amended in 1922, 1949 and 1978 (Department of Lands and Survey 1978, Wilson 1979). In 1998, the ownership of the Crown Tìtī Islands was vested in Ngāi Tahu by the Ngäi Tahu Settlement Act (1998) and these islands were renamed the "Rakiura Tìtī Islands".

The main periods of harvest are nanao and rama. During the nanao, which occurs from 1 April until mid/late April, the chicks are extracted from the burrows during daylight. Historically between nanao and rama there was also a pahure harvest phase; however, this is less commonly undertaken today. During pahure, birders pass over the birding ground during daylight for a second time, this time targeting "tarred" burrow entrances (those marked with down). The down is deposited by early emerging chicks that have come out at night to flex their wings and lose down, so tarring signals that a chick occupies the burrow. During the rama (or "torching" period) from late April until mid-May, the chicks are captured when they emerge from their burrows at night (Lyver 2000a, b, Hunter et al. 2000b).

Introduced rats (Kiore, Rattus exulans (Peale,1848); Ship or Black Rat, R. rattus (Linnaeus, 1758); and Norway Rat, $R$ norvegicus (Berkenhout, 1769)) are present on some Tìtī Islands. Stewart Island Weka (Gallirallus australis scotti (Ogilvie-Grant, 1905)), an endemic rail, was introduced to the Tìtî Islands early in the twentieth century by the Tìtî harvesters for food. Rats and especially Weka depredate Titi eggs and chicks and threaten harvest sustainability (Moller et al. 2003, Harper 2006, Dillingham et al. 2007, Harper 2007, Newman et al. 2008a).

\section{RESEARCH METHODS AND FRAMEWORK}

Establishment of the Kia Mau Te Tìtī Mo Ake Tönu Atu research program involved prolonged and repeated discussion between all members of the Rakiura Màori community and researchers over two years before the actual work began (Moller 
2001a). A "cultural safety" agreement was established between Rakiura Mãori and the University of Otago research team to secure trust and protect intellectual property rights from the mattauranga and to ensure that research methodology did not violate Māori tikanga (Moller 1996, Taiepa et al. 1997). This agreement ensures that while scientific data from the program are jointly owned, the TEK remains the intellectual property of Rakiura Māori. The agreement also stipulates that all written work resulting from the research program is reviewed and commented on by the "Rakiura Tìti Island Administering Body", which consists of representatives elected by the Rakiura Māori community. Before submission, the

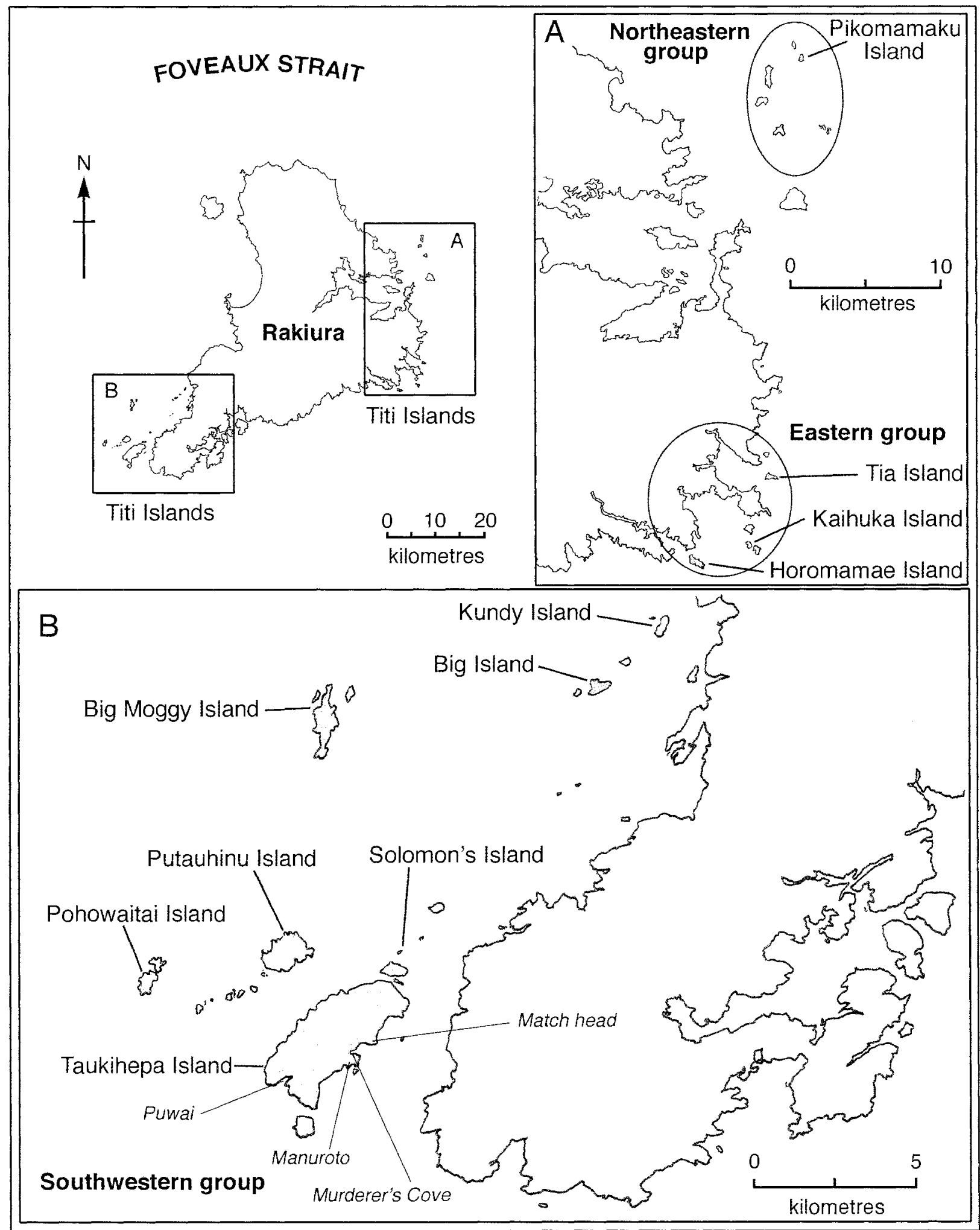

FIG. I - Rakiura (Stewart Island) and adjacent Tìtī Islands. Interviewees' birding islands are shaded and named. Specific birding areas (manu) are also named for Taukihepa. 
Administering Body validated this paper. There was much community concern about opening the traditional harvest to scrutiny of "outsiders" (Davis 2001, and discussion to papers in Howard \& Moller 2001). Thus it was important to proceed slowly and build confidence amongst all participants that the researchers would treat the information shared with respect and represent it accurately in publications. Equally, the cultural safety agreement protected the researchers' scientific ethics by stipulating that the Rakiura Mãori community could not prevent publication, irrespective of what the research concluded about the sustainability or otherwise of the harvest (Moller 1996, Moller et al. 2000). Repeated presentations and community peer reviews took place at annual hui (meetings) on marae (traditional Māori meeting places).

Although field-based ecological studies began in 1994, it was not until 1997 that trust was established sufficiently to begin interviews about mātauranga, the most culturally sensitive information of all. We interviewed 20 experienced muttonbirders, elders and kaumātua (respected elder, Garven et al. 1997). The selection of participants was non-random because we targeted older people who are more likely to have retained traditional management strategies. In many indigenous communities, elders play a key harvest management role - they are often the keepers, transmitters and interpreters of TEK (Berkes 2008, Berkes \& Folke 2002). For the purposes of our project, the interviewees had to be over 50 years old, still actively muttonbirding, and living in the Southland area. This project had an additional purpose, in fulfilling a request that the oral history from the kaumàtua of the Rakiura Māori community be recorded before the information was lost. Because of this, two kaumātua were interviewed even though they had not been birding since they were teenagers.

We used the standard practice and techniques employed by social scientists for identifying relevant informants (key informants, snowball techniques, triangulation, etc.) and conducting interviews (informed consent, open-ended questions; Denzin \& Lincoln 2003). The Rakiura Tìtī Islands Administering Body introduced us to two potential interviewees, who in turn suggested other elders to approach. The sample of interviewees consisted of seven females and 13 males who ranged from 55 to 85 years old (mean $=69$ years). A married couple were interviewed together at their request. The sample represented approximately $30 \%$ of the possible candidates who fitted the selection criteria at that time. The heterogeneity of practices and traditions on different islands was addressed by interviewing representatives of various families from 11 different islands and 17 manu (family birding territories on Tìtī breeding ground). The majority of interviewees had birded on the southwestern Tìrî Islands (fig. 1), where birding is concentrated. However, other Tìtī Islands were also well-represented by interviewees from an excellent cross-section of birding locations, shown in figure 1.

Four additional people approached for interviews declined. One refused because she apparently distrusted science and another distrusted researchers because a previous and unethical researcher had taped their conversation without her consent. The relatively high proportion of older birders interviewed and the low level of non-participation suggests that our information will be an unbiased representation of the views and knowledge of the older Tìtī harvesters in the community.

All interviews were conducted by JK. Before the "official" interview took place, she visited the prospective interviewees, in some cases a number of times, and spent time building up trust. In this pre-interview period, she asked them questions of a general and personal nature; however, during the majority of this period the questions came from the prospective interviewee. As JK is of Rakiura Mãori descent, it was important for the interviewees to find out how she related back to them, and to share accounts of her family members.

The interviews were unstructured (Lofland \& Lofland 1995 ) or lightly semi-directed (Huntington 1998, 2000), where direction and scope of the interview mainly followed the interviewee's train of thought and any guidance to emerging concepts by the interviewee only occurred for clarification, or occasionally at the end of the interview, if the birder had not already covered the ground. There was no fixed questionnaire, though an interview guide was referred to for prompting further discussion if there was a lull in conversation. The interviews took place between November 1997 and early March 2000 and were audiotaped and transcribed. All interviewees received an audio copy and transcript of the interview. If the interviewee was willing, a copy of the interview/s was lodged at the Southland Museum and Art Gallery, sometimes with restrictions placed on access and future use. Seventeen interviewees granted permission for their interviews to be lodged at the archive. Although many of the interviewees have been going to their island since they were very young children, they were very concerned about being singled out as "authorities" on muttonbirding. Confidentiality was assured to them in any publication; hence this manuscript refers to the participants as Birder A, B, C, etc.

Spoken language can appear quite ungainly when typed on a page. To aid readability, quotations from the transcripts have been edited to remove fillers (such as "um", "ah" and "you know" etc.), repeated phrases, false starts, pauses, laughs, and the occasional grammatical error. Occasionally, changes were also made to ensure confidentiality. Square brackets indicate where we have added text to aid understanding. Three reviewers (two from our research team and an independent expert on ethnographic research) compared the original transcript quotations with the edited quotes in this text to ensure that any changes made were to aid understanding and keep the original meaning intact.

\section{RESULTS}

\section{Access to the birding islands}

Access to the birding islands is conferred through Rakiura Māori hereditary rights and is controlled in two ways, depending whether the island is a Rakiura Tìtī Island or a Beneficial Tìtīi Island.

Any "Rakiura Māori" (as defined by statutory regulation) can apply for an annual permit for any of the Rakiura Tìti Islands. Applications for the permit are submitted to the Rakiura Tìtī Island Administering Body. Before the Tìtî season begins, permits for Rakiura Māori and their spouses are read out at an annual gathering of the birding community ("Permit Day"). Should a dispute arise from a permit, the individuals concerned have to prove their whakapapa in front of the gathering.

On Beneficial Islands, prospective birders must prove that they descend from one of the original owners of that island or, in the case of Taukihepa (fig. 1), the specific manu where 
they propose to harvest. To become a "beneficiary owner", birders must inherit their beneficiary rights from their parent when they die. The younger generations in those families are called "potential beneficiaries" and are allowed to bird with the permission of the family member who holds the beneficial right. Historically, decisions on particular islands or manu are made by the beneficiary owners:

My old people, when they were going to the islands, we had no say whatsoever. You did as you were told, and it worked out all right. We weren't the beneficiaries at that stage, they were the beneficiaries, [and] we were only potential [beneficiaries]. Whatever my Dad said went, that was it. (Birder E)

\section{Territoriality within islands}

Territoriality often forms part of the control of access within common property management systems (Berkes 1986). The forms of territory systems found on the Tìtī Islands can be broadly described as "closed" and "open". In a closed system, an area is allocated to each adult birder or each family on the island. In an open system, all the birders on the island can harvest anywhere on the island. The type of system in place and variations on these depend on the how the birders "worked" (organised the allocation of the resource) on that particular island, as the following quote from Birder C highlights:

Now we have our main manu [birding area] that is ours, and then if there's any left over, you share it per family. That's the way we work ours. The working rule[s] on all islands are different. I mean we work ours different from say likes of Pohowaitai. They work strips nanaoing but it's an open island for torching. But it all depends on the island. [The] likes of Putaubinu, they have their family manus regardless of how many on each manu. The people on the island make their own working mules. (Birder C)

On some islands the type of territory system in place varies according to the development stage of the Títī chicks. During nanao, some islands work in "strips", where all the birders work side-by-side, harvesting from one boundary to another on a pre-determined width of manu. For individuals the location of these strips could vary from year to year, or remain constant. During pahure, during which birders can go over the ground again before the rama period, access is generally open. Once rama begins, the islands become either open or closed systems. In those islands with open manu during rama, allocation management of territories occurs prior to the start of the season and is determined by the birders from that island. In some open systems, families allocate different times of night to harvest during rama, so that they do not deplete the number of emerged chicks available for capture. Some birders harvest during the early part of the night and others just before dawn, or they can take turns to harvest (Birder H; Moller 2002).

Historically, the kaumātua of the island determined birding territories. Boundaries are commonly demarked by tracks, creeks or other natural markers like edges of forest patches. Separate areas are allocated for men and women to work during the nanao on Horomaemae. Historically, the same happened on Big Island. On Pohowaitai, the allocation of harvest areas to groups of birders to work in strips during nanao is determined by one member from each group drawing a playing card; the person who draws the highest card has the first choice of area. Working strips requires that all the birders work together. If a day is to be taken off during nanao, then all the birders need to take that day off.

The territory systems are dynamic and systems on islands have changed over time. Some islands that had closed systems now have open ones, while Big Island has changed from a closed to open, and then back to a closed system over a lifetime. Birders have observed changes in the numbers of 'Tìtī as natural successional changes in vegetation make the habitat more (or less) suitable for the birds. On Big Island this resulted in an increase in the number of birders wanting to work the area as numbers of 'Títi increased. The island's closed system was opened as there was not sufficient land area to allocate individual manu, and the open system enabled the increased resource to be shared among a larger number of birders. As vegetation patterns continued to change, Tìtī numbers declined to a level where fewer birders wanted to work the area, once again allowing the allocation of individual manu and a return to a closed system.

\section{TIKANGA: THE RULES}

Certain traditional rules or tikanga apply to the harvest of Tìtī. Beginning with the framework set out in Folke t al. (1998), we explored "rules" or the ways in which birders "look after" the manu/island, within several categories: protection of habitat, keeping the manu tidy, protection of breeding burrows, tapu (access limits), temporal restrictions of harvest, protection of adults, and waste minimisation. We then consider overarching concepts of sanctions, compliance, reciprocity and learning for sustainability.

\section{Protection of habitat}

The interviewees placed a strong emphasis on rules for protection of habitat. Discouragement of unnecessary felling of live wood was strongly emphasised in nearly three-quarters of the interviews. In the past, firewood was a sought-after resource because of the reliance on open fires for use in the houses and for cleaning and cooking the chicks. Despite this high demand, the birders were only allowed to collect dead wood for firewood. Collecting firewood was something that the majority of the interviewees participated in as a child. Birder C recalls branding the dead trees in order to claim them as firewood, because there was such a demand for wood:

... through the season you didn't take trees that were standing and with all the houses on the island [with] open fires you'd have to go a long way [to collect wood], but [when] everybody would land [on the island] they'd rush and put their brand on the fallen trees that were closest, so if you were there early you got the closest trees. (Birder C)

Fire was controlled to minimise the risk of the fire spreading, but also because historically, before the advent of modern communications, lighting a fire on the landings was the only way to signal that someone on the island was ill and needed evacuation:

You were not allowed to light fires indiscriminately anywhere because fires were used as a medium of communication from island to island. And fire[s] had to be lit in a certain place; because of the composition of the soil on the island being peaty it could burn on for years and years if it got into the ground. (Birder D)

Fires are much less frequent in recent decades because coal and gas bottles for fuel can be transported by helicopter.

The cutting of tracks is necessary for access to manu, to 
transport harvested chicks, aid navigation and demarcate manu. Tracks need to be clear enough for the birders' safety (i.e., avoid scratching themselves, poking an eye out, or hitting their head on a low hanging limb, etc.) but not too wide to cause unnecessary damage to vegetation. Birders try to use old established tracks rather than establishing new ones, so as to avoid damage to breeding burrows, as can be seen from this extract:

... you're taught from when you're old enough to use a slasher that you mustn't cut your track too wide and too far back. [It's] got to be clear so that you're not going to run into sticks or that in the night, but you're taught how to cut your tracks so that you're just trimming it back each year and you're not going [to] damage your trees. So that you're sort of weaving your way through the trees, more than opening up big tracks because you're relying on the roots of those trees to bind all those holes [Tìti burrows] together and keep everything intact. If a tree grows up in the way you'll have to sacrifice it because you shouldn't deviate your tracks. Because if you do, you're tramping a different part of the ground. What happens over the years is that the stuff that you're cutting builds up on that ground. It gives more humus and everything and then the roots come through that and so where you're walking, is solid earth and you don't go through [collapsing a Titi breeding burrow]. (Birder K)

Tracks that are too wide and clear can be difficult to catch chicks on during the rama. Chicks will move from nearby fern and low scrub to sit on the track where the birder can harvest them. But if the track is too wide, the chicks will move off them faster to find cover as the birder approaches (Birder Q).

An exception to the prohibition to cut down live wood is when a tree is about to die, as evidenced by leaves curling and letting sunlight through the canopy (Birder $\mathrm{K}$ ). Tüpare, one of the main canopy species, has about a 30-50-year lifespan on the Tìtĩ Islands (Birders A, C, L; and see Hawke et al. 2003). If the tree will fall and damage the manu, it will be removed rather than allowing it to fall naturally (Birders C, $\mathrm{K}, \mathrm{R}$ ). However, some dead trees have an important purpose. Tìtì require a high point from which to jump for take-off. They typically jump from cliff tops or rock promontories, but in some cases they use trees as take-off points. If a takeoff tree has died, Birder $\mathrm{K}$ will try and retain that take-off tree, and in some cases has propped up individual trees in danger of falling. Birder $K$ has linked the abundance of birds in the area to the presence of these "airports":

A muttonbird is a pretty lazy sort of a guy, be won't walk any distance, if he can help it, so they'll use trees and that to climb up [and] to take-off from rather than go to the cliff. If one of those [trees] died you do everything that you can to preserve that take-off, because if those birds haven't got that tree to take off from, they won't bother nesting there. Near the centre of the island there was a big easy manu, which the women used to work. That was a women's manu because it was a nice easy ground to work because there was a nice big tree there for them to take off [from]. It was good birding in that area, there was a lot of birds there, and then the whole clump of trees got that old that the whole lot fell down, and all the leaves went in to those holes and you wouldn't even know that a muttonbird had ever nested there. It was just not a bird or a bole anywhere.
Then over the years more trees grew up but they still never nested there. The trees that grew up there was just a thick canopy - têtẽaweka just blocks the sun right out, and it wasn't until a big storm broke a big branch off and made a gap, and then they could come up that tree and out through the gap. And then all those birds came back and opened that area up and nested there again. So you never cut or damage one of the airports. (Birder K)

Birders $\mathrm{L}$ and $\mathrm{Q}$ mentioned planting of young trees in areas where the old trees died off. Birder $P$ planted young pünui (būnui, Stilbocarpa lyalli Gray) in response to damage caused by rats. The punnui is useful in keeping the breeding burrow entrances free of leaves (Birder P).

Unnecessary disturbance to other birds or vegetation is frowned upon (Birder E, F, L, P, O) and considered to cause the birds to move away, a reflection of a wider concept of reciprocity of care between the birds and the harvesters:

... they wouldn't allow you to cut down any trees - you could cut up all the trees that had fallen down, cut those up for wood - but they wouldn't allow you unless it was really urgent to cut down a living thing, because if you did the cycle would just finish. All the plants and that, they wouldn't allow you to kill off anything that you weren't supposed to. That includes the [adult] muttonbirds and all the bird life on the island, you couldn't touch them. You got chastised if you did harm any of the birds or bird life. The only bird life we were allowed to do anything with was wekas and muttonbirds [chicks] because they were things that we had to take to eat and to help with our diet. (Birder E)

\section{Keeping the manu tidy}

Another method of looking after your manu is to clear wood and debris from the manu (Birders D, F, G, I, L, M, R). In the past, a large amount of wood was removed from the manu and stacked for easy access to be used for firewood. Some birders still cut up dead trees and stack that and other dead wood in piles; however, this practice is not carried out on all islands (Birder O). Birder $\mathrm{R}$ recalls his grandparents "cleaning the manu". For some this practice was important in order to make the manu looked cared for (Birder R and $\mathrm{L}$ ) and it aided access for harvesting. Some also believed this practice promoted access for the birds themselves (Birder G and $L$ ):

... most people seem to try and keep the manu [tidy], you know stack old stuff that falls over and keep it sort of a bit tidy so that there's some open spaces rather than pushing your way through everything. It's [for] ease of access but I think it's probably better for the birds too 'cause they do struggle in the thick and I think they like the open manu too 'cause that's where they seem to have their burrows. (Birder L)

A practice that could also be considered "cleaning the manu" is clearing the burrow entrances of leaves. Birders I, $M$ and $P$ cleared out all burrow entrances of leaves and sticks during nanao regardless of whether they thought a chick was in the burrow or not. It is thought this practice might prevent the loss of empty burrows by encouraging birds to use them the following year.

An important "cleanliness" issue is the effective disposal of the entrails and waste products from processing chicks, such as wings and tails. Such waste products are mostly disposed 
of in the sea. Some islands with beaches can have this waste washed up on to them. Birders $\mathrm{O}$ and $\mathrm{P}$ harvest on such an island and they stressed the importance of people not disturbing the gulls that help clean the beach.

\section{Protection of the breeding burrows}

The protection of burrows was the most frequent management practice mentioned. Eighty percent of the interviewees said this was very important. Out of the four birders that did not mention this, three did not take part in the nanao or had not been to the islands since childhood. During nanao, if the chick cannot be reached, a hole is dug over where it is estimated to be to enable the chick to be extracted. This act is called whakaputa (Ashwell 1999). It is then important to plug or "puru" the hole to ensure the nest will remain dry and the adult bird will nest there again in the next season:

They [the old people] have always been pretty conscious of looking after their grounds especially the burrows. If you dig down a puru for to get a bird out you've got to plug that up properly or otherwise you ruin the hole, ruin the nest and the bird is not going to nest there next year. They were very fussy on that one. Don't destroy the holes that's the whole concept you know of not going on the island in the off season and everything else, don't disturb the breeding in any way and don't destroy the holes. And we've always been very conscious of that. (Birder F)

During nanao, birders are unlikely to harvest chicks on rainy days (Birders $C, N, Q, R, S$ ). The main reason for not harvesting in the rain is to avoid getting ill, and thereby missing the rama, which is the more productive harvest period. However, another reason for avoiding harvesting in wet weather was to protect breeding burrows:

... you couldn't go out in the rain, because the old people used to say it softens the ground too much and you can't plug the holes properly. So that was the why they wouldn't let them go in the rain. (Birder C)

\section{Tapu areas}

Designating areas as tapu is used as a way of preventing access to protect areas sensitive to habitat damage:

... there's some areas of the island that are tapu, you never ever work them because ground is so soft and the bole[s] are so near to the surface that if you did walk in there those holes would just collapse. ... you didn't go near there, you just left it for the birds to breed in that area, because if you went in there the holes would collapse. ... on a little island like ours whether you like it or not we've got to try and find birds because every hole matters. And then of course the tracks are worked out so that they sort of go round the perimeter of those sort of areas [tapu areas] so that you have a fair chance of picking those birds up at torching time. (Birder K)

Designating areas as tapu also prevents access to sacred sites associated with their ancestors (tizipuna) (Birders C, J, P):

... there's a woman and a baby buried there. And mind long before my time, but it's never nanaoed, [and] it's in the middle of my manu. And I've never nanaoed it. I've only known one person to nanao it, that was my brother-in-law, [a] Pākehā, and did he get told off. And it's got all sorts of dry wood on it but nobody goes in to get the dry wood, and even [in] torching time if there's birds on that side, and there always is, I never ever go on to it, no. [I] wait till they come off. (Birder C)

... we don't go where the old houses have been where the old people have lived. You will see rings of burnt rocks and you don't get wood there or anything like that. It's always sort of tapu to us. We just leave them. There are plenty of places you can go and you don't bird there. You don't go and nanao there. I know near where we are there's two big rings of old burnt black rocks where there have been houses and over further there's a patch and it's got all sorts of dry wood but you never ever go in there. (Birder P)

\section{Temporal restrictions of harvest - a disturbance reduction strategy}

An off-season räbui (ban), centuries old, applies to the islands and serves to prevent disturbance of the ground as well as the breeding adults while they are mating, incubating and, initially, rearing the chicks. As one birder relates:

... we were always taught [that] when a bird is nesting, you never go near it. Because that mother may leave the eggs, but once that the bird is hatched, the mother instinct then takes over and it will never leave it. It'll always keep looking after that bird. (Birder K)

In earlier times, temporal restrictions were also used to minimise the disturbance of the chick's normal emergence behaviour in late April and May, near the fledging stage. The pahure harvest period is viewed as important because it delayed the start of the rama period of night harvesting (Birder D, F, Q). These interviewees believed that if the rama begins too early then the chicks will fledge and leave the island earlier, thereby decreasing harvest opportunities. As one birder explains:

... the earlier you go out catching your birds and chasing them, the earlier they are going to jump over the cliff. They are like sheep. If you go out and chase the bloody things every night, they are going to run away as soon as they see you. So if you go out there on the 21st [April] you are starting the ball rolling. So after that when they see your light coming, they are off. I say leave it till later on and go about things quietly. (Birder Q)

Interviewees reported that if the chicks were frightened back down into their holes, they would stay there until the last possible moment, leaving the island immediately when ready, rather than emerging repeatedly and thereby being available for harvest in the rama period. One interviewee considered that abandonment of the pahure practice was a very important reason for the declines in catches in recent decades.

Birders referred to Rakiura Mãori having harvested other petrels on the muttonbird islands in earlier times, particularly korure (Mottled Petrel Pterodroma inexpectata (J.R. Forster, 1844),) and parara ("paras" Broad-billed Prion, Pachyptila vittata (Forster, 1777)). Birder L's mother placed a ban on korure harvest for her family's manu in 1949, after detecting a decline in numbers. That rāhui is still in place today.

\section{Days off: a conservation measure?}

Historically, Sundays were always a day taken off from harvesting. In some places, part of Saturday was taken off as well (Birders I, J, E). These were times for rest, social interaction, passing on traditional knowledge, and community 
assessment of the harvest, as well as religious observance: ... we would work from Monday through till Saturday lunch time and my old taua [grandmother] she wouldn't let them work after 12 o'clock on Saturday. That was the time that they had for themselves. It was free time and our uncles used to knock off work on Saturday lunchtime, have lunch, have a wash and change their clothing and they'd be away from one end, from Puwai right away to the other end of the island. Theyd spend the weekend away and come home again on the Sunday night. Yeah and those at the other end of the island. they'd do the same thing, come back to our end of the island. So yeab they would have a constant change of visitors and they would come and stay the night or just come and visit and go away. In the weekend there was always new faces around, around the house. There would be the old ones, the young ones and there's the young carrying younger ones ... (Birder E)

As another birder relates:

... you couldn't catch a bird on a Sunday and you couldn't go out torching on a Sunday night till after twelve. You weren't allowed to catch birds on a Sunday then. It was religious reasons. They used to have Bible readings, when we were small, every Sunday in the morning. (Birder C)

Birders $F, K$ and $M$ considered taking days off a conservation measure, because a number of chicks were spared because no harvest took place on that day:

And working Sundays, that was a sort of self-imposed conservation, because that was one day, one extra day, you didn't work birds. So many birds [were] saved sort of thing. (Birder F)

Families no longer collectively take Sundays off. However, they do set aside occasional days for socialising and fishing. On Big Island, Good Friday is a scheduled day off from harvesting and is spent socialising and sharing a meal. These days are usually between the nanao and rama period, when the birders have to wait until the chicks come out of the burrows at night in sufficiently large numbers. At the beginning of nanao, harvest can be delayed for several days if the chicks are deemed too young or small to harvest (Birders C, F, M, N, P, Q, R). The harvest begins when the chicks grow to a suitable size. This decision is made as a group, or by the "supervisor" elected by the group.

In historical times all the chicks were stored using $p \bar{o} h \bar{a}$ (kelp bags made from the lamina of Durvillaea antarctica (Chamisso) Hariot. This required additional days off from harvesting for curing, preserving and storing chicks (Birders $\mathrm{C}, \mathrm{D}, \mathrm{I}, \mathrm{M}, \mathrm{Q})$. Once tins (in the 1950s) and then plastic 10-litre pails with lids (from mid-1970s) became the common method of storage, these days off for preparation of the catch were no longer required:

... when I was a kid people down there used to have Sundays off and they would have another day off to cut up and they'd have another day off to pack the birds. Today there's no days off. She's all go. So bit of a lost part of the island, you know. (Birder M)

\section{Protection of adults}

Harvesting of Tìti is solely restricted to the chicks. The adult birds, kaiaka (also referred to as kaiaki, "mother birds", "parent birds", and "old birds"), are protected because they are the breeders. Killing an adult is considered the ultimate transgression:
There is the odd time where your foot will go through the ground and make a hole, [and] if anyone walked on and left that unplugged, that's one of the ultimate sins. That's probably the second worst thing you can do. The worst crime on an island is to kill a kaiaki [adult bird]. (Birder K)

If a child made a mistake in killing an adult they were sometimes made to pluck it (a very difficult task) so that they would be sure to remember to check the age of the bird before killing next time.

\section{Waste minimisation}

An important concept for some of the interviewees was not wasting Tìti or resources on the islands. Over half of the interviewees reported that kiaka (a chick that is too thin to take as food) are avoided. Only suitable chicks are killed, and this is done instantaneously so as to avoid unnecessary suffering. Most often the kiaka encountered early in the season are returned to the breeding burrow because the adult may return to feed them and "give them a chance" to survive. However, Birders J and P said that if they found a very weak kiaka they would kill it out of mercy rather than allow the rats to do so. Birders F, G, O, S and Q stated that it is important to harvest only as many chicks as they process. The way the chick is handled through the catching, processing and storage stages is important in order not to ruin the bird (Birder K). Chicks that become ripped, bruised or deemed unsuitable for sale, barter or gifting become "home" or "tucker" birds and are retained by the birders for their own food (Birder R, G, F, I).

\section{Sanctions, compliance and enforcement}

"Clubbing" has been banned on some islands and manu (Birder F and M). "Clubbing" involves the use of a small club to kill the chicks during rama. The main objection to this method is concerned with the possibility of wastage, as this method eliminates the need to handle chicks before killing them, introducing the possibility that small chicks and adults could be mistakenly killed. Bruising of the meat can occur, which makes it less suitable for sale. "Fencing", where Tìti are trapped during rama when they make their way to cliff take-off points, is another method that has been informally prohibited, because of the risk of wastage and harming adult birds. Both clubbing and fencing were formally banned by new bylaws passed for the Rakiura Tìtĩ Islands in 2008, but community sanctions based on tikanga had virtually eliminated the practice for several decades on all the islands.

Access to the Tìtī Islands is strongly protected. Beneficial owners have removed potential owners from the island, or prevented them from taking part in the harvest, if they damaged the island or misbehaved (Birder E and P; see also Wilson 1979). As one birder recounts:

... one year some [of] my cousins came down, [and] they didn't know anything about muttonbirding and they were just starting at the mouth of the hole and digging their way back until they found a bird. 'Cause theyd never been told and I remember they were told if they couldn't do it properly, [then] stay out of the bush. They weren't allowed to go out and that then. If you don't respect the island and things down there, well they always get told off and if you don't do it, the owners will get together and tell you to keep off the island. (Birder P) 
The tikanga or rules that protect the islands are debated fiercely at the annual Permit Day hui and any transgressions are noted and publicly aired. The rules are viewed as the one thing that the birders have direct control over and must protect at all cost to protect the birds and habitat:

I think the habitat and how we look after it is really important for the returning birds when they come back, because no matter what happens out there we're the only ones who have got control of the habitat 'cause there's no control in the ocean. There's so many things happening out there that we have got absolutely [no] control lover] unless we can convince Governments to stop pouring out pollution and all the things that have adverse effects in the ocean. So you know, we should do everything we can on the land to make sure that the ones that do come back have the very best habitat there is for them. (Birder L)

\section{Reciprocity, responsibility and learning for sustainability}

Birders believe that if they look after the manu, the birds will keep coming back and will continue the harvests for the generations to come:

I think how you look after an island dictates as to what will be on that island, because those birds keep coming back to that island. I know that the mothers do. Once they've nested, they will keep coming and nesting there again ... (Birder $\mathrm{K})$

In some of the interviews, the kaumàtua and elders mentioned a responsibility they had to look after the islands for the next generations and that it was important to pass on the knowledge and the resource to the next generations. This responsibility was given to them by their ancestors. This knowledge had been passed down to them from their parents or (in many cases) grandparents. Approximately a quarter of the birders stated that it is important for the next generations to be taught properly to look after the islands for the sustainability of the Titi and the cultural heritage of Rakiura Mãori. Looking after the land is also looking after your people:

I think kaitiakitanga is really looking after what is bere now and making it improve and grow. I see kaitiaki[tanga] as being what we have done on [our island]. I see it all being part of the lifestyle of the people on the island. But I [also] see it too as how we look after our families. Because that's kaitiaki[tanga] too. We are kaitiaki of those children and young people. Then it transfers on to the land. I see what we have done down there, how the island's starting to blossom, I see that being kaitiaki[tanga]. (Birder $\mathrm{L}$ )

Another birder relates:

... most of the people I know down there [on the Titit Islands] look after the muttonbirds. There's the odd one in every situation that don't - that are grabbers and don't care about the holes or the way the ground's left or anything. I have seen it myself. But the majority of them, thank God, are good conservationists. As long as that happens and you teach the young ones properly so that they come along to be good conservationists and look after that what you got, then you got no problem. $I$ don't and the [Forest and] Bird Society should not worry about it. Because if you have got to be told by somebody else how you should run something that you have had for generations, you're at the end of your tether. So you might as well stop. (Birder M)

Many birders emphasised the importance for the next generations to be taught properly to look after the islands for the sustainability of the Tîti and the cultural heritage of Rakiura Māori (Birders J, L, K, M, N, S).

\section{DISCUSSION}

\section{Mātauranga and tikanga for sustainable resource management}

The Tîtī harvest provides an important case study of TEK and common property theory in action within New Zealand. However, calls for reinstatement of customary harvest rights around the world (Posey 1996, IUCN 1997), and ensuing debates about the environmental safety of indigenous people's harvest management, broaden the conservation interest of this study. Our central inquiry was whether resource management rules exist to secure the sustainability of a culturally-defining customary harvest for the mokopuna.

Rules dictate the behaviour of Tìtī harvesters in relation to the resource. For example, rules ensure adult birds are not disturbed, only chicks of a suitable size are harvested and that wastage is minimised. However, the majority of rules focus on the protection of the habitat of the island, such as burrow integrity, care of vegetation and maintenance of manu areas. The potential threat to adult birds and possible wastage has prompted the development of rules banning certain techniques for harvesting Tìtī. These rules fit under the "method taboo" category of Colding \& Folke (2001). Similar rules are applied by Hauraki Māori when harvesting Grey-faced Petrels, Pterodroma macroptera gouldi (Hutton, 1869), in northern New Zealand (Lyver et al. 2008). While differing in specifics to match local ecology and behaviour, these rules fit into the categories established for other cultures' sustainable use of a common resource (Folke et al. 1998, Colding \& Folke 2001, Berkes et al. 2003).

Some Tìti harvest rules obviously serve several different functions at once and sometimes they were not justified or promoted for solely "conservation" or "sustainability" reasons. Indeed, we were struck by how infrequently the words conservation, sustainability and kaitiakitanga were mentioned by the interviewees. The matauranga and tikanga described to us was about the practice of birding and usually only secondary reference was made to their sustainability or conservation consequences. Similar observations of other indigenous communities have led some Western observers to discount lore as being a conservation mechanism, simply because it is not always enunciated as being directed or wholly-designed for a conservation purpose (Smith \& Wishnie 2000). This etic (outsider) perspective is tautological and based on cross-cultural presumptions about the design of social institutions. The more important debate is whether the lore protects the natural resource, harvest sustainability and social-ecological resilience, to deliver that harvest sustainability in the long term.

Adherence to the tikanga is fiercely reinforced within the Rakiura Māori community, both for managing the birders and controlling outside groups like researchers. For example, prohibition of our field ecology researchers visiting the manu early in the season was firmly enforced (Moller 2001a, Newman \& Moller 2005). The researchers required estimates of the number of eggs laid and the proportion 
that hatch and survive until the early chick phase (when the birders are not allowed to "walk on the manu") for the construction of computer models to estimate harvest sustainability. The researchers were therefore forced to measure the early season population parameters on other non-harvested study areas. Similarly, for a decade the researchers were prohibited from digging up burrows to check the accuracy of the burrowscope method used for estimating chick density and breeding success (Lyver et al. 1998, Newman et al. 2008 a, b, Scott et al. 2008). The kaitiaki reluctantly permitted the researchers to dig a very small number of plots with breeding burrows only when all other methods to check the accuracy had been exhausted (McKechnie et al. 2007). Even then digging was focused as much as possible on sites where new buildings were soon to be erected (the burrows on those sites were soon to be disrupted anyway), and the very laborious traditional puru technique had to be used to reseal the burrows after plots had been surveyed. These cultural restrictions on research are akin to the ethics guidelines operating in wider society, but crucially different in their adherence to local tikanga. A third example of cross-cultural differences in research ethics related to researchers' requests to attach radio-transmitters to adults. Even though the transmitters were within internationally recognised research standards for size and attachment method, the kaitiaki were extremely sceptical that they would not disturb the birds and insisted on a trial using dummy transmitters in a colony away from the harvested manu before they would authorise more widespread telemetry. To the researchers' surprise, the trial did find evidence of disruption to colony attendance from having the transmitters attached (Söhle et al. 2000), and wider use of telemetry was abandoned after the initial six deployments (Söhle et al. 2007). Matching research ethics to local tikanga retained community confidence in the research and minimised disturbance to the habitat and adult birds, but scientific inferences were weakened and the culturally appropriate alternative research paths were more expensive and less powerful. More importantly in the context of this discussion, the tikanga and mātauranga of the birders was demonstrated to be alive and well, vigorously asserted and, in the case of the telemetry example, both accurate and valuable.

Tikanga stipulating an imperative to only take what can be processed is very important for sustainability because the time available for harvesting and processing the chicks places a direct limit on the number of Titì harvested. With the current technology, the amount of time it takes to process the chicks limits the number of chicks that can be harvested without wastage (Lyver \& Moller 1999a, b, Lyver 2000 b, Kitson 2002). There are no rules that dictate the number of Tìtì birders can harvest from a particular area, or on a given day, per season, or per person participating. This finding is consistent with other studies of wildlife harvests by Māori in New Zealand (Moller \& Lyver in press) and of indigenous resource users in general (Wilson et al. 1994, Colding \& Folke 2001). It leads to many observers characterising indigenous harvest management as "passive", "compared to active" management of the size of the take itself that is normally promulgated by Western wildlife management regimes. However, our research recorded many and varied active rules by which sustainability is promoted indirectly.

One of the most important harvest rules is the protection of breeding adult birds, which has also been highlighted as the most vulnerable life stage to harvest for long-lived seabirds. Seabirds are long-lived and have low productivity, so the demographic impacts of harvesting chicks are much less than if adults are taken (Lyver \& Moller 1999b, Hunter et al. 2000a, Moller 2006, Moller \& Lyver in press). Tikanga prescribing that the very small "kiaka" chicks should be left will have negligible impact on sustainability towards the end of the season because these starved chicks do not survive anyway (Sagar \& Horning 1997, Hunter \& Caswell 2005). However, returning the smaller chicks to their burrows early in the nanao period does potentially reduce harvest impacts because feeding by the adults in the last stages of the fledging period can rapidly increase chick size, thereby lifting more of the chicks over the threshold where they may survive to recruitment stage.

The râhui preventing access to the islands until late in the chick phase is probably particularly important for reducing breeding failure and emigration by pre-breeding birds. Scientists have also found that Tìtī are susceptible to disturbance in the egg phase (Warham \& Wilson 1982). Rapid decline of the Fisher Island population of Short-tailed Shearwater was apparently triggered by repeated handling and disturbance at the colony in early and mid-stages of the breeding season (Serventy \& Curry 1984). This sensitivity to disturbance is believed to be a common phenomenon in procellariids (Warham 1996).

Tapu is a central concept in the Māori culture (Metge 1976, Marsden 1981, Irwin 1984, Patterson 1994). Everything designated as tapu must either be avoided or handled with care according to prescribed rules (Metge 1976). Tapu is normally understood as prohibition (Irwin 1984), but in resource management its function can be for protection (Irwin 1984, Puia 1990). Declaration of tapu areas can be important for protecting resources and habitats in some areas. For example, the ground on one of the small Tìi Islands is extremely fragile and susceptible to burrow collapse because the native Tüpare has been displaced by a shallowrooting invasive tree species. However, on most islands the tapu areas are small. Also, all tapu areas will only provide a partial refuge from harvest for chicks, as some chicks will move out of these areas just before fledging and may therefore be captured.

Overall, only $15 \%$ of the Sooty Shearwater breeding ground within the Rakiura Tìti Islands is not harvested (Newman et al. 2008a). This area mainly comprises small islets that are either too steep or too small to support a whānau for birding. Within the birded ground, additional protection by tapu is very limited and can thus be excluded from consideration in quantitative assessments of the sustainability of the harvests, at least as a direct effect. However, observance of tapu will have a much greater indirect effect on Tītī harvest sustainability by reinforcing reciprocity and observance of tikanga, especially the very important rähui provisions (protection of adults, banned access to the islands early in the breeding season). Scientific reductionism that separates rāhui from a wider context of tapu, reciprocity, identity and place will obviously fail to recognise a whole package of interrelated tikanga and world view that promotes sustainability in indirect ways.

\section{Access, compliance, lore and law}

Rakiura Māori have both informal and formal institutions to govern their behaviour. Social mechanisms (informal institutions) can be far more effective and are less costly as 
compliance and enforcement mechanisms because of their self-regulatory nature (Colding \& Folke 2001). For common property resource management to work, it is important for the resource users to believe that abiding by the rules will bring benefits to them as individuals. Effective self-regulation is expected to be especially important in managing use of resources in remote areas like the Tìti Islands, so this is a common motivation for instituting co-management in such places (Moller 1996, Taiepa et al. 1997, Moller et al. 2000). In particular, social sanctions function as guides for human conduct towards the natural environment (Colding $\&$ Folke 2001).

While the harvest had been governed by traditional rules, in 1910 Rakiura Mãori petitioned the New Zealand Government to recognise most of these rules as legal regulations (Land Act Regulations 1912, Department of Lands and Survey 1978). This legal recognition was seen as a way to negate any changes to island land use and open access to others, for example leaseholds and farming (Wilson 1979, Birder L). There was also concern that the Tìtī resource would be exploited by northern Māori. Accordingly, access to the Tîti Islands became strongly protected by law in a way that reflected lore.

Reinforcement of lore and law has been an ongoing and collaborative effort of the Rakiura Māori community and government. At Permit Day hui, permission for access goes through close community scrutiny and sometimesheated debate. In the past, trespass has been penalised by confiscation of harvest and public notification of the offence. Pākehā have also been prosecuted and penalised for trespass on the islands (Southland Times 3 July 1913). Historically, blood has been spilt in fights between island owners and trespassers on the islands (Wilson 1979). The testimony of our interviewees and government files (formerly of the Lands \& Survey Department; then Department of Conservation) record repeated and ongoing debates about who does and does not hold harvest rights and instances of community interventions to reinforce access rules. These access rules are upheld just as vigorously today. For example, in the late 1960 s, one interviewee was stopped at the wharf just before embarking to the island because he had not gone through the Màori Court and gained a succession order to allow him to go to the island. Bell (1962) recorded discussion about regulations not being followed in all their details. Correspondence on Lands $\&$ Survey files in the early 1970 s report concerns that the supervisors were not asserting their traditional authority or that birders were not heeding it, so the Commissioner of Crown Lands for awhile visited during the birding season, accompanied by the supervisors, to provide a more visible presence on islands. In 2003, at the request of beneficial owners, the Department of Conservation removed nonbeneficiaries from two manu in 2003 (S. Owen, pers. comm.). In 2004, a photographer was forcibly removed from the islands because he was not a Rakiura Màori, even though he was being hosted by a birder with rights. The eyes and ears of the birders effectively police the access to the islands and use of the law to reinforce lore is obviously frequent and effective. This reinforces a strong sense of community agency and responsibility.

There has been repeated reference in Permit Day hui over the past 14 years of research to the way the muttonbirding laws were requested, designed and reinforced by the tūpuna. The birders see the legal regulations as their own regulations and consider that they must be protected and reinforced continually. In contrast, some Rakiura Māori individuals talking on the marae have occasionally reported their transgression of Resource Management Act and Conservation Act laws applied to management of other resources on the mainland, or even expressed some pride in transgressing where those laws are seen as nonsensical or not reflecting lore.

While the muttonbirding regulations broadly reflect traditional lore, some of the provisions clearly serve a more bureaucratic and surveillance role for government. Legal regulations instituted powers on "supervisors" which traditionally were exercised by kaumātua. Supervisors are appointed for each island at Permit Day hui prior to the season. They have legislated roles in settling disputes during the birding season, reinforce the regulations and provide an annual summary of the total number of chicks harvested from their jurisdiction. Several birders have indicated to the researchers that the latter are widely disregarded and inaccurate. Birders closely guard their harvest tallies from each other, so a legislated requirement to declare the level of catch is largely ignored. The above examples indicate that simply regulating new requirements, like supervision and harvest reporting, is unlikely to succeed if not embraced by the majority of harvest practitioners themselves. If accepted by the majority, law can then be exercised to enforce compliance of miscreant individuals.

There is potential for law to reinforce traditional social structures, such as hierarchies based on age, but substitution of traditional authority by law by itself is unlikely to empower self-regulation for sustainability. Elders play a key role as the keepers of TEK, transmitting knowledge and providing wisdom to interpret novel observations (Berkes 2008). That respect of elders for their knowledge and authority is still strong in the Rakiura Màori community is reflected in the way the community directed the researchers to seek the testimony of the kaumātua for this research. However, some interviewees expressed concern that younger people were no longer respecting their elders and the lore (Moller \& Kitson, unpublished data) and one kaumātua goes further to assert that some of the older ones are actually frightened of some of the younger community members (Bragg \& Newman 2004).

Incorporation of Christian beliefs into Māori tikanga is widespread and reflected in recitation of Christian prayers in many community activities. In some instances, such beliefs have even been transferred into law. For example, regulations applying until 1962 stated that: "No work in connection with the taking or preserving of the muttonbirds shall be done before 6 pm on any Sunday" (Land Act Regulations 1949, amendment No.3 (1962)). Amendment of law is time-consuming and expensive, so it is perhaps inevitable that aspects of the law will not closely match current lore. The way law affects customary harvest management is a potentially important and unstudied aspect of adaptive co-management of natural resources by indigenous peoples throughout the world. In which circumstances will it help retain traditional management methods and protect sustainability, and in which might it hinder?

While instigation of legal regulations to reflect lore can be seen as promoting sustainability, it could never be a complete substitute for the tikanga and detailed knowledge that is continually being exercised to protect the birds and the breeding habitats. The past or current regulations do not cover protection of vegetation, yet the majority of interviewees stressed the importance of this. This indicates the 
presence of social sanctions that are still guiding behaviour of Tìti harvesters at a much more subtle and detailed level in ways that will be very important for sustainability.

\section{Common property resource management theory}

The Tìti and the land on which they breed is communally owned and managed. Common property theory operates where the exclusion of potential users is difficult and the activity of each user subtracts from the welfare of all the others (Berkes 1989, Feeny et al. 1990). It might seem that the remoteness of the Tìti Islands should afford a level of protection by excluding other potential users. In fact, journeys to the islands in canoes were undertaken for centuries (Davis 1999) and in contemporary times commercial fishers regularly land to take "lunchtime birds" during the season (J. Kitson \& H. Moller, unpubl. data). The promulgation of the muttonbirding regulations was partly motivated to protect the resource from North Island Māori and non-Màori, but strident debate at annual Permit Day hui throughout this study period has repeatedly focused on access issues, associated "birding rights", and reinforcement of boundaries between manu amongst Rakiura Māori's own community. Government correspondence files demonstrate that these have been ongoing concerns since the early 1920 s. Notwithstanding these debates, it is widely believed that by adhering to the rules, which are reinforced by legislation and cultural and social sanctions, the birds will return, providing an incentive for individuals to comply. This study therefore confirms that Rakiura Māori Tītī harvesting practice is an example of common property resource management. The collective international empirical evidence of the efficacy of common property law for resource protection (Berkes 1989, Feeny et al. 1990, National Research Council 2002) therefore gives us confidence to assert the power of the tikanga to create the necessary platform for sustainable management of Tìtì.

\section{Adaptive co-management and learning for sustainability}

Adaptive co-management emphasises the importance of learning and creation of new social institutions to meet new sustainability challenges (Berkes \& Turner 2006, Turner \& Berkes 2006). The experience and wisdom of TEK holders provide the context for this flexibility in rules (Hviding 1998, Berkes \& Folke 2002). An important aspect for enduring cultural and ecological sustainability is the mechanisms by which TEK is received, accumulated and then transmitted to the next generation (Ohmagari \& Berkes 1997, Folke et al. 1998).

Our study has shown that rules, sanctions and harvest organisation can be different on different islands. The harvesters reorganise and adapt to new situations and circumstances while still keeping within the generally-defined bounds of acceptable social behaviour. Turning lore into law is a dramatic cross-cultural adaptive co-management adjustment. Application of ecological science alongside tikanga and mātauranga for sustainability is another powerful example of adaptive co-management by the kaitiaki of the Tìtî. Although the majority of the community supported and therefore chose to go ahead with the Kia Mau Te Tìti Mo Ake Tónu Atu research program, some individuals opposed it throughout its 14-year duration. One interviewee in another study using confidential questionnaire approaches summed up his concern by saying "beware of strangers bearing gifts" (Moller 2003). The predominating concern was that the research brought external scrutiny and therefore the possibility of external interference in harvest management.

The Rakiura Māori community have also adapted to embrace many other contemporary tools and institutions for wildlife management and island ecosystem restoration. Tìtī harvesters on the eastern Tìtî Islands (fig. 1), which are regularly re-infested by rats from the main Rakiura island, combine efforts and resources in an attempt to control rat numbers (Birders $\mathrm{P}$ and $\mathrm{H}$ ) by laying rat poison. Birders combined forces with the Department of Conservation to eradicate Kiore from Putauhinu (Davis 2004). Following the drowning of a banded Títi in a 1998 oil spill off San Francisco, the birding community successfully petitioned an oil spill reparation fund in the USA to pay for eradication of Ship Rats and Kiore and more recently Weka from four Tîtī Islands (Moller et al. 2003, Coote \& Blackwell 2006) Eradication of introduced predators has enabled transfers of threatened bird species, such as Codfish Island Fern-birds, Bowdleria punctata wilsoni Stead, 1936, and led to a resurgence in plant, insect and other bird life, helping to restore the ecosystem. The community's adoption of these international and contemporary wildlife management and research tools was combined with their local knowledge, voluntary effort and community authority to reduce rat infestation from $48 \%$ to $17 \%$ of the Titi breeding area.

\section{Reverence for life, reciprocity and learning for sustainability}

Our research adds to a growing body of international case studies (reviewed by Berkes 2008) to show that indigenous societies' resource and habitat protection rules function similarly to westernised conservation management. For example, habitat protection is a large part of westernised resource management and Rākiura harvesting rules and the tikanga minimise disturbance, protect breeding stock and sometimes promote escape from harvest in just the same way as scientific management. Some of the parallels found in the results of international studies reflect common ground between the approaches of different cultures to environmental management. This is likely to represent convergent cultural evolution of different knowledge systems to meet common challenges of ecology, social-ecological resilience and sustainable resource extraction. This convergence arises despite notable differences in the specific cology and behaviour of the hunted species and social institutions operating in divergent cultures and communities.

An overarching Māori world view emphasises interconnection between people and their environment and between current generations and their ancestors as part of a wider reciprocity (Roberts et al. 1995, Patterson 1994, Kawharu 2002). Threaded through the testimony of the kaumātua we interviewed was a fundamental concept of reverence for life and reciprocity. There have been many instances over the 14 years of this study where non-Màori have communicated their distaste of Māori harvesting wild and/or native animals, and especially their chicks. These observers consider muttonbirding as showing disrespect for nature and life, tantamount to sacrilege. However, 
the Tìti harvesters asserted many rules for promoting life on the islands and profound reverence for the Tití, their beauty and strength. Simple direct examples include the staunch rules such as protection of living trees and all adult birds. Some birders practise mercy killings of starving chicks in much the same way that animal welfare ethics are applied in wild food harvesting and agriculture (Matthews 2008).

More fundamentally, many birders confidently assert a general belief that harvested populations are more healthy and ecologically resilient. Similar constructs are found in the mātauranga concerning other customary harvests of wildlife by Māori (Moller \& Lyver in press). Efforts to clear the manu and keep it tidy were expected to promote overall abundance of the birds. In the early phases of "bringing in" a manu when it is first worked, some birders deliberately shorten breeding burrows in the belief that this would promote the number of birds breeding in the area. This was mentioned to the research team by other muttonbirders during the 14 years of study ( $\mathrm{H}$. Moller, unpubl. data), but none of our interviewees mentioned it, presumably because their manu had been long established on traditional ground. Similarly, Richdale (1944) reported that the 1942 birding season was very poor and that the birders believed this was because the burrows had not been cleaned out because birders had not visited the islands the previous season (World War II disrupted normal birding). Populations with greater resilience might result from density dependence, the main ecological mechanism by which harvest off-take could be compensated (Moller 2006), but this would require reduction in local density. There is tentative evidence of density-dependent regulation in the Tîti population, in part triggered by improved breeding success in less densely burrowed ground (Newman et al. 2008a, in press).

Reciprocity between the harvesters and the birds can be approached by the ecological linkages, such as the postulated density dependence mechanisms. However, a deeper and more fundamental recognition of reciprocity underlies the expectation of some birders that the Títi will move away if they or their habitats are disrespected. Some Tìtī harvesters drew our attention to a deep relationship between the birds and the people. These birders consider the birds have feelings and their own agency in that relationship. For example, some birders expressed their belief that the birds "called the researchers to us [the Rakiura community]" to help arrest declining bird numbers (e.g., see the discussion by Tane Davis in the Whakamutunga o Te Hui (farewell) session in Howard \& Moller 2001). Other birders, who have been sceptical of the value of the Kia Mau Te Tìtì Mo Ake Tönu Atu research program, have expressed their opinion that an upsurge in numbers and condition of the birds in 2007 and 2008 seasons was a direct result of the field research ending in 2005 (R. Clucas, unpubl. data). One of those birders stated that the birds have felt a "weight lifted off their shoulders" by the research ending. These are examples of some kaitiaki seeking support and guidance from the birds themselves. It is a fundamentally different construct from Western wildlife management approaches where broadly scientific decision making operates. Both approaches are motivated by care, but science is nevertheless applied to manage birds that are considered passive recipients, whereas some birders speak of a two-way interaction between people and the birds that operates at a metaphysical level. This is an example from the Tìti case study of the "belief" component of TEK's knowledge-practice-belief nature (Berkes 2008).
Metaphysical beliefs cannot be confronted on science terms but nevertheless must be acknowledged in science and mātauranga partnerships being directed by an indigenous community level (Moller 2001b).

Transgenerational reciprocity and responsibility was also emphasised repeatedly by the kaumantua of the Tìtî community. Current kaitiaki expressed their responsibility to uphold the tikanga and continue the màtauranga because it was required of them by their tūpuna as much as by their mokopuna. Transgenerational equity is at the core of the conservation ethic of all cultures and ethnicities. However, the inclusion (some kaitiaki would say participation) of the tūpuna in the dialogue and decision making of the Tìtī community has been frequent and emphasised. This inclusion makes discourse and decision making in the community fundamentally different from that we have experienced in scores of forums concerning harvest and conservation management by Pākehā over the past 14 years since the Kia Mau Te Tìtì Mo Ake Tönu Atu program began.

\section{Environmentality and kaitiakitanga}

It is important that Rakiura Mäori retain the control of Tìtī harvesting, both for the Tìti per se and for their cultural wellbeing. Societies do not establish conservation rules and ethics for the benefit of outsiders (Berkes 2008). Incursions of outsiders and the inability of a group to defend an important resource have been shown to cause the lifting of rules and the decline of conservation ethics (Feit 1986, Berkes 1986, Berkes et al. 1989). The very name given to the research program, Kia Mau Te Tìtī Mo Ake Tönu Atu ("Keep the Tìtì forever"), was repeatedly referred to as a double imperative, that is, to ensure that the birds remain plentiful enough for the mokopuna but also for the kaitiaki to retain management control of the islands and the harvest. The provisions of the cultural safety contract guiding research co-management were mainly designed with the second objective in mind. The experience of partners in environmental co-management (Moller 1996, Taiepa et al. 1997, Moller 2001a) and the emerging theory of environmentality (Agrawal 2005) focus on appropriate governance institutions to trigger individual transformations amongst resource users' subjectivities about the environment. Promotion of the agency of locals, sharing authority and devolution of power to create meaningful roles in resource monitoring and harvest regulation are seen as key to building responsibility and voluntary compliance. The effectiveness of subsidiarity and bottom-up approaches to conservation management telies on individual commitment to local community goals, especially when resources are communally-owned and harvest activity may be relatively solitary and remote from the scrutiny of others. 'The reality is that effective external management of the Titi harvest by traditional wildlife management lore would be practically impossible. The theory of environmentality predicts that imposing rules from outside the culture and community would also be fundamentally undesirable. In contrast, Tìtī harvesters have a strong sense of ownership of the tikanga and rules, which they believe must be upheld at all costs, in order to protect the birds and habitat. 


\section{Ahi kā roa: keeping the fires burning for the mokopuna}

Integration of seasonal movements and hunter gathering, maintenance of knowledge and occupancy over successive generations is referred to as a hi ka roa (keeping the fires burning) by Māori (Roberts et al. 1995). At the final community hui where the researchers presented Tìti sustainability predictions from science to the Rakiura Māori community (Murihiku Marae, 5 July 2008), a kaumātua summed up his assessment of the science as "only numbers" and followed by emphasising the need to reassert the tikanga and find ways for the mâtauranga to be transferred to the younger generation (Moller 2008). This is linked to the issues of pride and responsibility, many Māori would say mana (prestige), as environmental stewards and being able to sustain and provide resources for their own people and manuhiri (visitors) (Waitangi Tribunal 1991). Birder M summed it up nicely as: "if you have got to be told by somebody else how you should run something that you have had for generations, you're at the end of your tether. So you might as well stop". Like many of the simple and direct comments of the Tìtī harvesters, this is a powerful statement of the inter-relationship between identity, agency, responsibility and sustainability.

\section{ACKNOWLEDGEMENTS}

This research primarily was funded by the Foundation for Research, Science and Technology who also granted Jane Kitson a Tüāpapa Pütaiao Mãori Fellowship. Further financial assistance was received from Te Rünanga o Ngäi Tahu. This research was reviewed and approved by the Ethics Committee of the University of Otago (Permit Numbers 97/004 and F02/001). We would like to thank the Rakiura Titi Island Administering Body for their support and guidance and the kaumàtua and experienced muttonbirders who were interviewed. Thanks to Julia Stroud, Ronda Peacock and Detta Russell who helped with transcription of the interviews and supported in many other ways. Helen Frizzle, from the Oral History Unit at Presbyterian Support Services, provided oral history equipment and methodology advice. Our perspectives on the Rakiura Tìtî harvest were shaped partly by comparisons with the Tasmanian Yolla harvest. Dr Irynej Skira guided us around some of those muttonbirding operations in Tasmania in 1999 and it was obvious that he had a strong and mutually respectful relationship with the Yolla harvesters. His interest in history and support of traditional uses of the environment makes the inclusion of this paper in his memorial volume all the more fulfilling. Thanks also go to Theresa Downs, Ben Knight, Phillip Lyver, Zane Moss, Mere Roberts and Sicily Sunseri who reviewed earlier versions of the manuscript. Aku mibi nui ki a koutou (we greet and thank you all very much).

\section{REFERENCES}

Agrawal, A. 2005: Environmentality: Technologies of Government and the Making of Subjects. Duke University Press, Durham: 325 pp.

Anderson, A. 1996: Origins of Procellariidae hunting in the Southwest Pacific. International Journal of Osteoarchaeology 6: $403-410$.

Anderson, A. 1997: Historical and archaeological aspects of muttonbirding in New Zealand. New Zealand Journal of Archaeology 17: 35-55.

Ashwell, H. 1999: Te Reo Mãori me ka Pepeha o tiwi Rakiura ma Wai Urua i te Heke Hao Kai Tìti i ka Ra Kua Pahure. Māori words and sayings as spoken by the people of Rakiura and Foveaux Straits. University of Otago Wildlife Management Report, Number 116. Dunedin, New Zealand: 35 pp.

Bell, B.D. 1962: Southern Mutton Birding Investigation. Unpublished Report to Conservator, Wildlife Service, Department of Internal Affairs. $15 \mathrm{pp}$

Berkes, F. 1986: Common property resources and hunting territories. Anthropologica 28: 145-162.

Berkes, F. (ed.) 1989: Common Property Resources: Ecology and Community Based Sustainable Development. Belhaven Press, London: $302 \mathrm{pp}$.

Berkes, F. 2008: Sacred Ecology. 2nd Edition. Routledge, New York: $336 \mathrm{pp}$.

Berkes, F., Feeny, D., McCay B.J. \& Acheson, J.M. 1989: The benefits of the commons. Nature 340: 91-93.

Berkes, F., Colding, J. \& Folke, C. 2000: Rediscovery of traditional ecological knowledge as adaptive management. Ecological Applications 10: 1251-1262.

Berkes, F., Colding, J. \& Folke, C. 2003: Navigating Socialecological Systems. Building Resilience for Complexity and Change. Cambridge University Press, Cambridge: 393 pp.

Berkes, F. \& Folke, C. 2002: Back to the future: ecosystem dynamics and local knowledge. In Gunderson, L.H. \& Holling, C.S. (eds): Panarchy: Understanding Transformations in Human and Natural Systems. Island Press, Washington, DC: 121-146.

Berkes, F. \& Turner, N.J. 2006: Knowledge, learning and the resilience of social-ecological systems. Human Ecology 34: $20-36$.

Bragg, C. \& Newman, J. 2004: Norman and James York. Father and son talk Tîtī. Tìtì Times 13: 6-7.

Colding, J. \& Folke, C. 1997: The relations among threatened species, their protection, and taboos. Conservation Ecology [online] 1: 6. URL: http://www.consecol.org/voll/iss1/ art6.

Colding, J. \& Folke, C. 2001: Social taboos: "Invisible" systems of local resource management and biological conservation. Ecological Applications 11: 584-600.

Coote, R. \& Blackwell, G. 2006: Rats removed! Titì Times 18: 2-3.

Dacker, B. 1990: The People of the Place: mabika kai. New Zealand 1990 Commission, Wellington, New Zealand: 39 pp.

Dacker, B. 1994: Te Mamae me te Aroha. The Pain and the Love A History of Kai Tahu Whanui in Otago, 1844-1994. University of Otago Press in association with the Dunedin City Council. Dunedin, New Zealand: 154 pp.

Davis, J. 1999: Mahinga Kai o Te Tītī. How can we estimate a time frame when iwi Māori began to harvest the tîtî? Tìtī Times 6: 7.

Davis, J. 2001: Te kaha te hikoi o te tangata. In Howard, M. \& Moller, H. (eds): He Minenga Whakatù Hua o Te Ao "Sustaining the fruits of the land". Proceedings of a hui, Murihiku Marae 25-27 August 2000. Online at: http:// www.otago.ac.nz/Zoology/hui

Davis, J. 2004: Kiore off Putauhinu: gone but not forgotten. Tìtī Times 13: 4-5.

Denzin, N.K. \& Lincoln, Y.S. (eds) 2003: Collecting and Interpreting Qualitative Materials, 2nd Edition. Sage, California: $682 \mathrm{pp}$.

Department of Lands and Survey 1978: The Tïti (Muttonbird) Islands Regulations 1978/59. Land Act Regulations 1949, Wellington, New Zealand.

Dillingham, P., McKechnie, S., Harper, G., Fletcher, D. \& Moller, H. 2007: A model-based assessment of the impact of predator control on populations of Tìti (Sooty Shearwaters; Puffinus griseus). Report prepared for Ka Mate 
Ngā Kiore (Kill the Rats) Incorporated Society. University of Otago Wildlife Report: No. 206: 30 pp

Feit, H.A. 1986: James Bay Cree Indian management and moral considerations of fur bearers. In Native People and Renewable Resource Management : the 1986 Symposium of the Alberta Society of Professional Biologists : Westin Hotel, Edmonton, Alberta, 29 April-1 May 1986: pp. 49-65.

Feeny, D., Berkes, F., McCay, B.J. \& Acheson, J.M. 1990: The tragedy of the commons: twenty-two years later. Human Ecology 18: 1-19.

Folke, C., Berkes, F. \& Colding, J. 1998: Ecological practices and social mechanisms for building resilience and sustainability. In Berkes, F. \& Folke, C. (eds): Linking Social and Ecological Systems: Management Practices and Social Mechanisms for Building Resilience. Cambridge University Press, Cambridge: 414-436.

Gadgil, M., Berkes, F. \& Folke, C. 1993: Indigenous knowledge for biodiversity conservation. Ambio 22: 151-156.

Garven, P., Nepia, M. \& Ashwell, H. 1997: Te Whakatau Kaupapa o Muribiku: Ngäi Tahu Resource Management Strategy for the Southland Region. Goodall, M. (ed.), Aoraki Press, New Zealand: 136 pp.

Harper, G.A. 2006: Weka (Gallirallus australis) depredation of sooty shearwater/titi (Puffinus griseus) chicks. Notornis 53: 318-320.

Harper, G.A. 2007: Detecting predation of a burrow-nesting seabird by two introduced predators, using stable isotopes, dietary analysis and experimental removals. Wildlife Research 34: 443-453

Hardin, G. 1968: The tragedy of the commons. Science 162: $1243-1248$.

Hawke, D., Newman, J., Moller, H. \& Wixon, J. 2003: A possible early muttonbirder's fire on Poutama, a Rakiura tìtî island, New Zealand. Journal of the Royal Society of New Zealand 33(2): 497--507.

Howard, M. \& H. Moller (eds) 2001: He Minenga Whakatū Hua o Te Ao "Sustaining the fruits of the land". Proceedings of a hui, Murihiku Marae 25-27 August 2000. Online at: http://www.otago.ac.nz/Zoology/hui

Hunter, C.M. \& Caswell, H. 2005: Selective harvest of sooty shearwater chicks: effects on population dynamics and sustainability. Journal of Animal Ecology 74: 589-600

Hunter, C.M., Moller, H. \& Fletcher, D. 2000a: Parameter uncertainty and elasticity analyses of a population model: setting research priorities for shearwaters. Ecological Modelling 134: 299-323.

Hunter, C.M., Moller, H. \& Kitson, J. 2000b: Muttonbirder selectivity of sooty shearwater (titi) chicks harvested in New Zealand. New Zealand Journal of Zoology 27: 395-414.

Huntington, H.P. 1998: Observations on the utility of the semidirective interviews for documenting Traditional Ecological Knowledge. Arctic 51: 237-242.

Huntington, H.P. 2000: Using traditional ecological knowledge in science: Methods and applications. Ecological Applications 10: $1270-1274$.

Hviding, E. 1998: Contextual Rexibility: present status and future of customary marine tenure in Solomon Islands. Ocean and Coastal Management 40: 253-269.

Irwin, J. 1984: Māori World View. An introduction to Māori religion: its character before European contact and its survival in contemporary Màori and New Zealand culture. Australian Association for the Study of Religions. Bedford Park, South Australia: 4-31.

IUCN Intercommission Task Force on Indigenous People 1997: Indigenous People and Sustainability. Gland, Switzerland: $364 \mathrm{pp}$.

Kawharu, M. (ed.) 2002: Whenua: Managing our Resources. Reed, Auckland: $400 \mathrm{pp}$.

Kitson, J.C. 2002: What limits the number of tīī (Puffinus griseus) harvested by Rakiura Māori in New Zealand? Human
Ecology 30: 503-521

Lofland, J. \& Lofland, L.H. 1995: Analyzing Social Settings: a Guide to Qualitative Observations and Analysis. 3rd Edition. Wadsworth Publishing Company, California: 288 pp.

Lyver, P. O'B. 2000a: Sooty Shearwater (Puffinus griseus) harvest intensity and selectivity on Poutama Island, New Zealand, New Zealand. New Zealand Journal of Ecology 24: 169-180.

Lyver, P. O'B. 2000b: What limits the harvest of Sooty Shearwaters (Puffinus griseus) on Poutama Island? New Zealand Journal of Zoology 27: 381-393.

Lyver, P.O'B. 2002: The use of traditional environmental knowledge to guide Sooty Shearwater (Puffinus griseus) harvests by Rakiura Māori. Wildlife Society Bulletin 30 $29-40$.

Lyver, P.O., Hamilton, S., McKenzie, M., Dickson, I., Dooher, M.T., Broad, T. \& Moller, H. 1998: A burrowscope for examining petrel nests in burrows. Conservation Advisory Science Notes 209: 1-21.

Lyver, P.O'B. \& Moller, H. 1999a: Modern technology and customary use of wildlife: the harvest of Sooty Shearwaters by Rakiura Mãori as a case study. Environmental Conservation 26: $280-288$

Lyver, P.O’B. \& Moller, H. 1999b: Tîtī harvests by Rakiura Māori: a case study of the use of Mãori Traditional Environmental Knowledge for sustainable natural resource management. Proceedings of Landcare Conference, Wellington 21-23 April, 1999. Published on Landcare Research Web page: http://www.landcare.cri.nz/conferences/manaakiwhenua/

Lyver, P.O'B., Davis, J., Ngamane, L., Anderson, A. \& Clarkin, P. (2008): Hauraki Maori matauranga for the conservation and harvest of Titi, Pterodroma macroptera gouldi. Papers and Proceedings of the Royal Society of Tasmania, 142(1): $149-160$.

Marsden, M. 1981: God, Man, and Universe: a Māori view. In King, M. (ed.): Te Ao Huriburi, The World Moves On. Longman Paul, Auckland, New Zealand: 142-163.

Matthews, L.R. 2008: Methodologies by which to study and evaluate welfare issues facing livestock systems of production. Australian Journal of Experimental Agriculture 48: 1014-1021.

McKechnie, S., Fletcher, D., Moller, H., Scott, D., Newman, J. \& Bragg, C. 2007: Estimating and correcting for bias in population assessments of sooty shearwaters. Journal of Wildlife Management 71: 1325-1335.

Metge, J. 1976: Basic concepts in Māori culture. The Māoris of New Zealand: Rautahi. Routledge and Kegan Paul, Auckland, New Zealand: 54-74.

Moller, H. 1996: Customary use of indigenous wildlife Towards a bicultural approach to conserving New Zealand's biodiversity. In McFagen, B. \& Simpson, P. (eds): Biodiversity: Papers from a Seminar Series on Biodiversity. Science and Research Division, Department of Conservation, Wellington, New Zealand, 14 June-26 July 1994: 89-125.

Moller, H. 1999: Full-on muttonbirding - when did it start? Tìtí Times 6: 7

Moller, H. 2001a: Co-management of a bicultural research project: a reseatch provider's perspective. In Howard, $M$. \&. H. Moller (eds): He Minenga Whakatū Hua o Te Ao "Sustaining the fruits of the land". Proceedings of a hui, Murihiku Marae 25-27 August 2000

Moller, H. (ed.) 2001b: Tîtī Times, Issue 8 (Special Science and Mātauranga Edition). University of Otago, Dunedin: 28 pp.

Moller, H. 2002: Tïtī harvests from an island east of Rakiura, 1983-2002. University of Otago report to manu owners: $72 \mathrm{pp}$.

Moller, H. 2003: Kaitiakitanga o kā Tītī I. A Māori Community's view of a science project to protect a customary wildlife harvest. University of Otago Wildlife Management Report: 
No. 801-2: 105 pp.

Moller, H. 2006: Are current harvests of seabirds sustainable? Acta Zoologica Sinica 52 (Suppl. Issue 1): 649-652.

Moller, H. 2008: A final sustainability research hui ... the community peer reviews our science synthesis. Titi Times No. 20.

Moller, H., Horsley, P., Lyver, P.O'B., Taiepa, T., Davis, J. \& Bragg, M. 2000: Co-management by Māori and Pākehā for improved conservation in the $21^{\text {st }}$ century. In Perkins, H. \& Memon, A. (eds): Environmental Planning and Management in New Zealand. Dunmore Press, Palmerston North: 156-167.

Moller, H. \& Lyver, P.O'B. in press: Using traditional ecological knowledge for improved sustainability: case studies from four customary wildlife harvests by Māori in New Zealand. In Hughes, C. (ed.): Indigenous People and Biodiversity Conservation. Conservation International, Arlington.

Moller, H., Nevins, H.M. \& Adams, J. 2003: The Rakiura Titi Restoration Project: Mitigation of the Command oil spill injury by eradication of rats from Sooty Shearwater breeding colonies in New Zealand. Report for Rakiura Tīici Islands Administering Body: 78 pp.

National Research Council 2002: The Drama of the Commons Committee on the Human Dimensions of Global Change. Division of Behavioral and Social Sciences. National Academy Press, Washington DC: 521 pp.

New Zealand Conservation Authority (NZCA) 1997: Māor Customary Use of Native Birds, Plants and Other Traditional Materials. New Zealand Conservation Authority, Wellington, New Zealand: 185 pp.

Newman, J. \& Moller, H. 2005: Use of Mātauranga (Māori Traditional Knowledge) and science to guide a seabird harvest: Getting the best of both worlds? In Kishigami, N. \& Savelle, J.M. (eds): Indigenous Use and Management of Marine Resources. Senri Ethnological Studies No. 67: 303-321. National Museum of Ethnology, Osaka.

Newman, J., Clucas, R., Moller, H., Fletcher, D., Bragg, C., Mckechnie, S. \& Scott, D. 2008a: Sustainability of Tìti harvescing by Rakiura Māori: a synthesis report. University of Otago Wildlife Report. 210: $118 \mathrm{pp}$.

Newman, J., Fletcher, D., Moller, H., Harper, G., Bragg, C., Scott, D. \& McKechnie, S. in press: Improved estimates of breeding success for a burrow nesting petrel, the Sooty Shearwater (Puffinus griseus), from nine years of monitoring. Wildlife Research.

Newman, J., Scott, D., Fletcher, D., Moller, H. \& McKechnie, S. 2008b: A population and harvest intensity estimate for Sooty Shearwater, Puffinus griseus on Taukihepa (Big South Cape), New Zealand. Papers and Proceedings of the Royal Society of Tasmania 142(1): 177-184.

Ngāi Tahu Settlement Act 1998: Crown Tīî̄ Islands. Ngāi Tahu Claims Settlement. No. 97. Part 13, Published under the authoricy of the New Zealand Government, Wellington, New Zealand: 502-507.

Ohmagari, K. \& Berkes, F. 1997: Transmission of indigenous knowledge and bush skills among the western James Bay Cree Women of Subarctic Canada. Human Ecology 25: $197-222$.

Patterson, J. 1994: Mãori environmental virtues. Environmental Ethics 16: 397-409.

Posey, D.A. 1996: Traditional resource rights. International instruments for the protection and compensation for indigenous peoples and local communities. IUCN. Gland, Switzcrland: $110 \mathrm{pp}$.

Puia, S. 1990: Protection and cultural use: Māori concepts of the relationship between Māori people and nature. In Towns, D.R., Daugherty, C.H. \& Atkinson, I.A.E. (eds): Ecological Restoration of New Zealand Islands. Conservation Sciences Publication No.2. Department of Conservation, Wellington: 272-277.

Richdale, L.E. 1944: The Sooty Shearwater in New Zealand. The
Condor 46: 93-107.

Roberts, M., Norman, W., Minhinnick, N., Wihongi, D. \& Kirkwood, C. 1995: Kaitiakitanga: Māori perspectives on conservation. Pacific Conservation Biology 2: 7-20.

Sagar, P. \& Horning, D. 1997: Mass-related survival of fledgling sooty shearwaters Pufinus griseus at The Snares, New Zealand. Ibis 140: 329-339.

Scott, D., Scofield, P., Hunter, C. \& Fletcher D. 2008: Decline of Sooty Shearwaters Puffinus griseus on The Snares, New Zealand. Papers and Proceedings of the Royal Society of Tasmania. 142(1): 185-196.

Serventy, D.L. \& Curry, P.J. 1984: Observations on colony size, breeding success, recruitment and inter-colony dispersal in a Tasmanian colony of Short-tailed Shearwaters Puffinus tenuirostris over a 30-year period. Emu 84: 71-79.

Skira, I.J. 1990: Human exploitation of the Short-tailed Shearwater (Puffinus tenuirostris). Papers and Proceedings of the Royal Society of Tasmania 124: 77-90.

Skira, I.J. \& Wapstra, J.E. 1980: Occupation of burrows as a means of estimating the harvest of Short-tailed Shearwaters Puffinus tenuirostris in Tasmania. Emu 80: 233-238.

Skira, I.J., Wapstra, J.E., Towney, G.N. \& Naarding, J.A. 1986 Conservation of the Short-tailed Shearwater Puffinus tenuirostris in Tasmania, Australia. Biological Conservation 37: 225-236.

Smith, E.A. \& Wishnie, M. 2000: Conservation and subsistence in small-scale societies. Annual Review of Anthropology 29: $493-524$

Söhle, I., Moller, H., Fletcher, D. \& Robertson, C.J.R. 2000: Telemetry reduces colony attendance by sooty shearwaters (Puffinus griseus). New Zealand Journal of Zoology 27: 357-365.

Söhle, I.S., Robertson, C.J.R., Nicholls, D.G., Mouritson, H., Frost, B. \& Moller, H. 2007: Satellite tracking of sooty shearwaters (Puffinus griseus) during their pre-laying "exodus" and incubation. Notornis 54: 180-188.

Southland Conservation Board 1994: Submission Report. Department of Conservation, Invercargill, New Zealand.

Southland Times (Invercargill) 3 July 1913. Exclusively for Māori: Muttonbird Islands. A case in court

Stevens, M.J. 2006: Kāi Tahu me te hopu tītī ki Rakiura: an exception to the "colonial rule"? Journal of Pacific History 41(3): 273-291.

Stevenson, M.G. 1996: Indigenous knowledge in environmental assessment. Arctic 49: 278-291.

Taiepa, T., Lyver, P., Horsley, P., Davis, J., Bragg, M. \& Moller, H. 1997: Co-management of New Zealand's conservation estate by Māori and Päkehā: a review. Environmental Conservation 24: 236-250.

Turner, N.J. \& Berkes, F. 2006: Coming to understanding: developing conservation through incremental learning in the Pacific Northwest. Human Ecology 34: 1-1.9.

Waitangi Tribunal 1991: Ngäi Tahu Report. Brooker and Friend, Wellington, New Zealand: $1254 \mathrm{pp}$.

Warham, J. 1996: The Behaviour, Population Biology and Physiology of the Petrels. Academic Press, London: 613 pp.

Warham, J. \& Wilson, G.J. 1982: The size of the Sooty Shearwater population at the Snares Islands, New Zealand. Notornis 29: $23-30$.

Wilson, E. 1979: Titi heritage: The Story of the Muttonbird Islands. Craig Printing Co. Ltd, Invercargill, New Zealand: 181 pp.

Wilson J.A., Acheson, J.M., Metcalf, M. \& Kleban, P. 1994: Chaos, complexity and community management of fisheries. Marine Policy 18: 291-305.

(accepted 5 August 2008) 